\title{
Mengajar Engineering Design Process Untuk Memperkenalkan STEM Pada Siswa Madrasah Ibtidaiyah Raudhatul Qur'an
}

\author{
Deny Nusyirwan, Eko Prayetno, Sapta Nugraha, Harits Aditya Nugraha, Lilis Agustina \\ Sinaga, Allysia Shafira, dan Muhammad Abyan Fadillah \\ Faculty of Engineering, Raja Ali Haji Maritime University \\ denynusyirwanl@umrah.ac.id
}

\begin{abstract}
Abstrak
Saat ini, pekerjaan di industri yang tumbuh paling cepat didominasi dengan pekerja dengan keterampilan Sains, Teknologi, Teknik, dan Matematika (STEM). Untuk menjadi kompetitif, penyedia pekerjaan membutuhkan tenaga kerja yang dapat beradaptasi dengan tempat kerja yang berubah. STEM memberdayakan individu dengan keterampilan untuk sukses dan beradaptasi dengan dunia yang terus berubah tersebut. Dengan latar tersebut di lakukan kegiatan pengabdian masyarakat dengan nama pelatihan Tech for Kids (TFK), yang menitik beratkan pada pembelajaran Engineering Design Process untuk memperkenalkan STEM pada siswa. Anak-anak memiliki kepribadian insinyur secara alami. Dimulai dengan rajin untuk mengotak-atik puzzle yang berupa potongan potongan kecil dari sebuah gambar utuh dan membangun serta membongkar dan menyatukannya kembali. Anak-anak mampu membuat penyesuaian secara cepat dan berimprovisasi tanpa memiliki rasa takut untuk menemukan sesuatu yang baru. Kemampuan berfikir secara luas yang diperkenalkan didalam proses pembelajaran TFK, mampu menyadarkan siswa akan pentingnya teknologi. Demikian juga sekolah yang termotivasi untuk mendorong siswa tidak hanya menjadi pengguna teknologi. Meningkatnya keinginan siswa selama kegiatan berlangsung telah menunjukkan keberhaSilahkann dari pelatihan TFK
\end{abstract}

Kata Kunci: Berfikir, Siswa, STEM, Tech for Kids

\begin{abstract}
Today, jobs in fast-growing industries are dominated by workers with science, Technology, Engineering and Mathematics (STEM) skills. To be competitive, job providers need a workforce that can adapt to a changing workplace. STEM empowers individuals with the skills to succeed and adapt to this changing world. With this background, community service activities were carried out by the name of the Tech for Kids (TFK) training, which focused on the Engineering Design Process learning to introduce STEM to students. Children have a natural personality. Diligently tinker with puzzles that are small pieces of a whole picture and build and dismantle and put them back together. Children who are capable of filming quickly and improvising without the fear of discovering something new. Broad thinking skills introduced in the TFK learning process are able to make students aware of the importance of technology. Likewise, schools are motivated to encourage students not only to become technology users. Increased desire of students during activities which shows evidence of TFK training
\end{abstract}

Keywords: think, student, STEM, Tech for Kids 


\section{PENDAHULUAN}

Revolusi Industri Keempat bertujuan untuk mendorong peningkatan pendapatan global dan kualitas hidup penduduk di seluruh dunia. Pada saat ini, yang mendapatkan manfaat terbesar adalah pengguna yang mampu mengakses dunia digital. Pemesan transportasi dan membeli produk serta pembayaran tagihan dapat dilakukan dari jarak jauh dengan menggunakan teknologi. Teknologi telah memungkinkan produk dan layanan baru yang meningkatkan efisiensi dan kesenangan kehidupan pribadi.

Teknologi dan industri mengalami perubahan yang cepat, maka sistem pendidikan dan pelatihan perlu diarahkan untuk mengembangkan keterampilan untuk memenuhi permintaan pasar. Untuk menghasilkan tenaga kerja Industri 4.0 kompetitif dan bersaing, maka diperlukan keterampilan Sains, Teknologi, Teknik, dan Matematika (STEM) yang kuat. Oleh karena itu, perlu dikembangkan kemampuan STEM yang dibutuhkan di masa depan dengan menyelaraskan kurikulum pendidikan dengan keterampilan yang relevan dengan industri. Dengan kurangnya pengetahuan dan penguasaan teknologi akan berakibat pada kurangnya pengetahuan untuk menggali potensi daerah sekitarnya. ${ }^{1}$ Sehingga akan mengganggu peningkatan taraf hidup dan perekonomian daerah setempat. Dimana pada ahirnya akan mengganggu perekonomian Negara. $^{2}$

Saat ini, pekerjaan di industri yang tumbuh paling cepat didominasi dengan pekerja dengan keterampilan STEM. Untuk menjadi kompetitif, penyedia pekerjaan membutuhkan tenaga kerja yang dapat beradaptasi dengan tempat kerja yang berubah. STEM memberdayakan individu dengan keterampilan untuk sukses dan beradaptasi dengan dunia yang terus berubah tersebut. Pekerja yang tidak siap akan berakit terganggunya proses produksi terganggu sehingga pesanan barang yang sampai kepada konsumen akan terlambat yang mengakibatkan siklus produksi juga menjadi lebih lama. ${ }^{3}$

Tidak semua kurikulum STEM dibuat sama, jadi penting bahwa saat mengintegrasikan STEM kepada siswa, dapat disusun sebuah program yang memungkinkan penelitian dan pemecahan masalah di dunia nyata. Salah satu cara untuk melakukannya adalah dengan mencari program STEM yang telah dirancang dengan menggunakan Engineering Design Process (EDP). Proses ini, memberi siswa kesempatan untuk mengembangkan proses pemecahan masalah yang merupakan solusi di dunia

\footnotetext{
${ }^{1}$ Rizqi Ilmal Yaqin, Boby Wisely Ziliwu, Bobby Demeianto, Juniawan Preston Siahaan, Iskandar Musa, Yuniar Endri Priharanto, Rudi Efendi, Muhammad Ali Rozaki, Nirmala Efri Hasibuan, Muhammad Nur Arkham. 2020. Edukasi Perawatan Motor Diesel Kapal Nelayan Desa Pelintung Kota Dumai, Warta Pengabdian, Vol. 14, No. 3, hal 200-209

${ }^{2}$ Ridho Alfarisi, Robiatul Adawiyah, Lusiana Ulfa Hardinawati, Mutiara Bilqis. 2020. Pendampingan Pengolahan "Bolen Durian Lumer" Sebagai Produk Unggulan Desa Pakis Dalam Peningkatan Perekonomian Masyarakat, Warta Pengabdian, Vol. 14, No. 2, hal 78-86

${ }^{3}$ Luh Putu Indah Budyawati, Arie Rahayu Hariani, Wiwin Hartanto. 2020. Mengadopsi Model Akuntansi Startup untuk UMKM: Studi Kasus pada Pengerajin Kayu Desa Grenden, Kabupaten Jember, Warta Pengabdian, Vol. 14, No.3, hal 181-190
} 
nyata. Keseimbangan yang tepat diperlukan antara masukan guru tentang konsep baru dan aplikasi siswa dari pembelajaran ini dengan cara yang mereka pilih ${ }^{4}$

Anak-anak memiliki hak yang sama dengan manusia dewasa, yang harus dihargai. Anak memiliki hak untuk berkembang dan terhindar dari diskriminatif karena anak adalah amanah yang diberikan oleh Allah. ${ }^{5}$ Dengan latar tersebut di lakukan kegiatan pengabdian masyarakat dengan nama pelatihan Tech for Kids, yang menitik beratkan pada pembelajaran Engineering Design Process untuk memperkenalkan STEM pada siswa.

\section{METODE PELAKSANAAN}

Engineering Design Process (EDP) adalah salah satu strategi yang tersedia untuk mengimplementasikan pendidikan STEM ${ }^{6}$. Dengan menguasai EDP, tidak mengatakan bahwa siswa akan tumbuh dan menjadi seorang insinyur, tetapi ada baiknya siswa mempelajari dan memahami apa yang dilakukan oleh seorang insinyur, yaitu proses memecahkan masalah melalui desain Gambar 1.

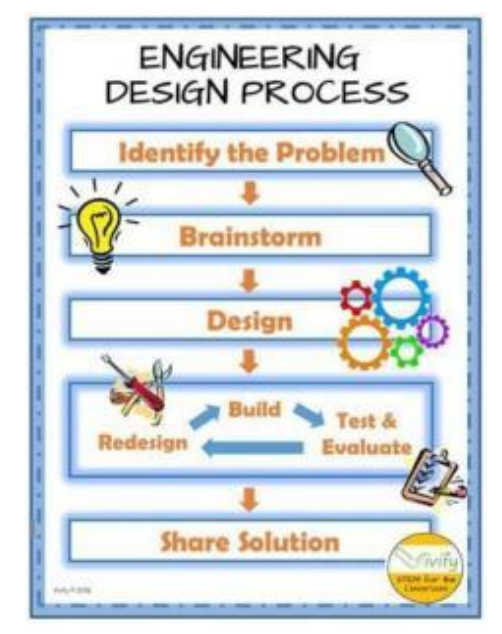

Gambar 1. Engineering Design Process ${ }^{7}$

\footnotetext{
${ }^{4}$ Lyn D. EnglishDonna KingDonna King, 2015, STEM learning through engineering design: fourth-grade students' investigations in aerospace, International Journal of STEM Education, Vol. 2, No. 1

${ }^{5}$ Rosnida Sari, Sutri Sanova. 2020. Faktor Anak Bekerja di Tambang Emas:Studi Kasus di Tambang Emas Blang Leumak, Aceh Jaya, Warta Pengabdian, Vol. 14, No. 2,hal 94-107

${ }^{6}$ Nur Rosliana Mohd Hafiz and Shahrul Kadri Ayop, 2019. Engineering Design Process in Stem Education: A Systematic Review, International Journal Of Academic Research In Bussines and Social Sciences, Vol. 9, No. 5, hal. $676-697$

7 Teaching The Engineering Design Process - STEM Activities for Kids [Daring], Tersedia pada: https://id.pinterest.com/pin/398779741988713981/ [ Diakses : 16 September 2020 ].
} 
STEM yang dilandaskan dengan EDP membawa kesadaran kepada siswa tentang potensi mereka sebagai pemecah masalah, pemikir, pencipta, dan kolaborator. Siswa mampu secara bersamaan memperluas batasan pengetahuan dan kompetensi mereka meskipun mereka mengalami kesulitan dalam mengatasi tantangan yang terkait dengan kegiatan STEM $^{8}$. Selain itu, memperkenalkan EDP adalah sebuah usaha dalam mengembangkan kreatifitas siswa untuk tidak tergantung kepada keterbatasan nya bantuan maupun ancaman yang ditimbulkan yang dapat mengganggu kesejahteraan ${ }^{9}$

\section{HASIL PENGABDIAN PADA MASYARAKAT}

Tanjungpinang adalah sebuah kota yang berlokasi di Pulau Bintan, Provinsi Kepulauan Riau. Lokasinya yang berdekatan dengan negara tetangga Malaysia dan Singapura, mendorong Kota Tanjungpinang untuk wajib memiliki SDM yang mampu menggerakkan ekonomi Provinsi Kepulauan Riau guna berkompetisi secara global. Gambar 2 menampilkan lokasi Pengabdian Kepada Masyarakat yang dilaksanakan di Madrasah Ibtidaiyah Raudhatul Qur'an Tanjung Pinang.

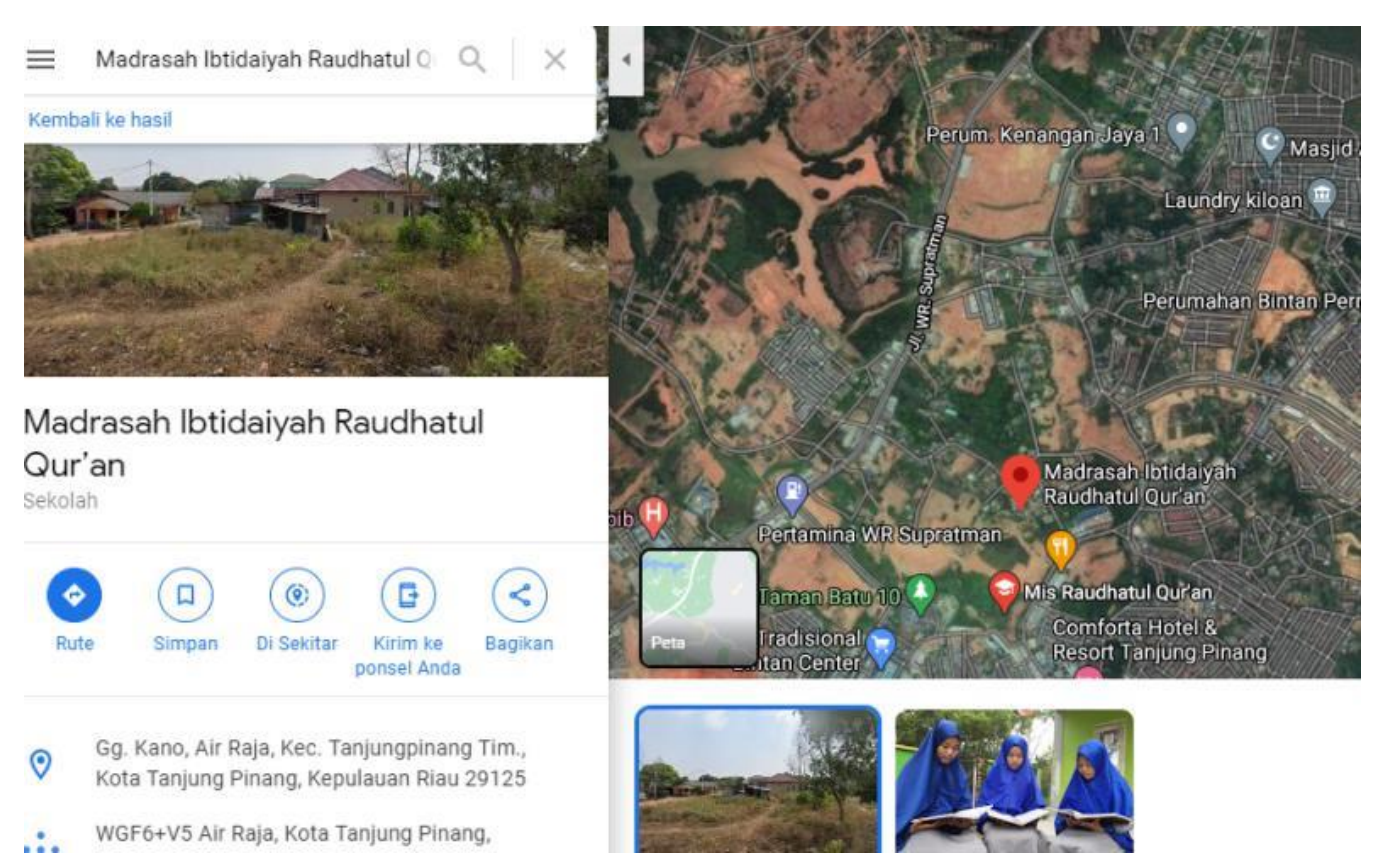

Gambar 2. Madrasah Ibtidaiyah Raudhatul Qur'an ${ }^{10}$

\footnotetext{
${ }^{8}$ Siew, NM, Goh, H, Sulaiman, F, 2016. Integrating Stem In An Engineering Design Process: The Learning Experience Of Rural Secondary School Students In An Outreach Challenge Program, Journal of Baltic Science Education, Vol 15, No. 4, hal 477-493.

${ }^{9}$ Novi Anoegrajekti, Sudartomo Macaryus, Asrumi, Hanni Miladia Maharani. 2020 Diversifikasi Usaha Sanggar Seni untuk Meningkatkan Kesejahteraan, Warta Pengabdian, Vol. 14, No. 1, hal 9-22

${ }^{10}$ Madrasah Ibtidaiyah Raudhatul Qur'an [Daring], Tersedia pada : Lokasi Madrasah Ibtidaiyah Raudhatul Qur'an [Daring], Tersedia pada: https://maps.app.goo.gl/IFyEQSRZQ6pjScjT9 [ Diakses: 16 September 2020 ].
} 
Selanjutnya pada Gambar 3 memperlihatkan keadaan sekolah Madrasah Ibtidaiyah Raudhatul Qur'an

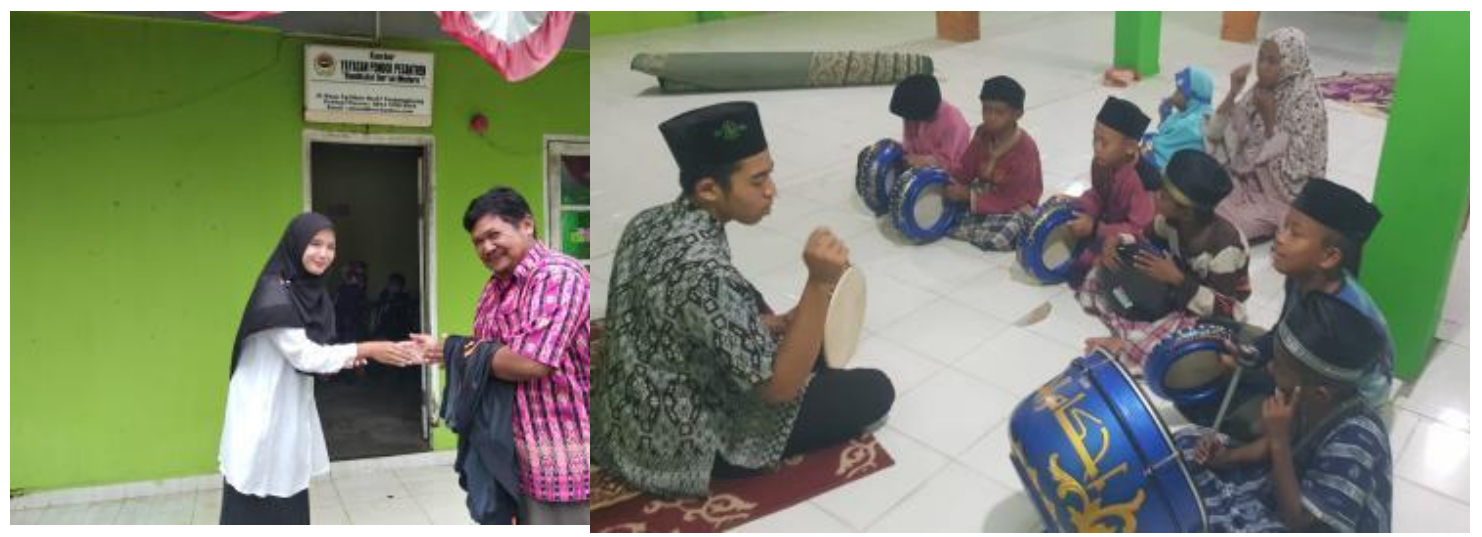

Gambar 3. Madrasah Ibtidaiyah Raudhatul Qur'an

Pertemuan awal memberikan penjelasan mengenai pelatihan Tech for Kids dan pemahaman kepada siswa mengenai EDP beserta tahapannya yang dilakukan oleh tenaga pengajar, Silahkan lihat Gambar 4. Pada minggu selanjutnya mahasiswa yang berperan sebagai fasilisator pelatihan akan mendampingi siswa untuk menghasilkan luaran pada ahir kegiatan nantinya.

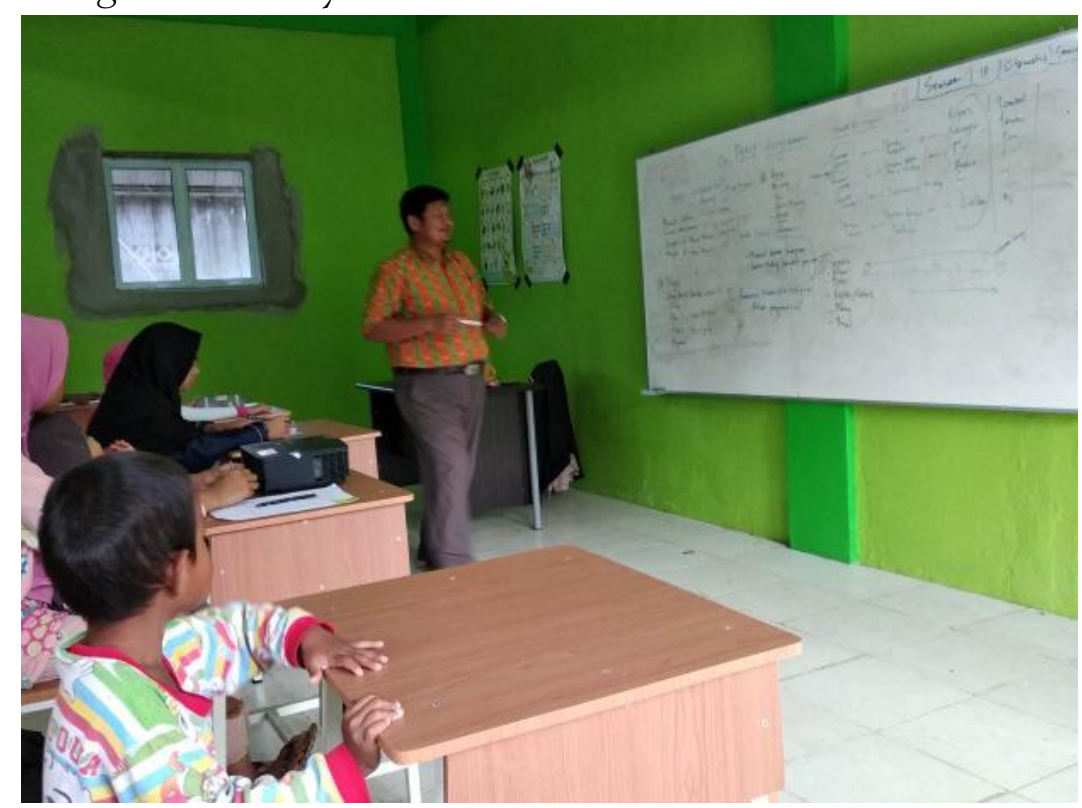

Gambar 4. Tenaga Pengajar Memberikan Penjelasan Mengenai Pelatihan Tech For Kids Dan Pemahaman Kepada Siswa Mengenai EDP 
Setelah memberikan informasi awal mengenai EDP kepada siswa, maka tahapan pelatihan pelatihan Tech for Kids dapat dimulai dengan urutan sebagai berikut:

\section{A. Identifikasi Permasalahan melalui Etnografi dan Brainstorming}

Etnografi sudah dikenal luas tidak hanya oleh kalangan Antropologi namun juga oleh perusahaan yang bergerak di bidang inovasi. Dengan memanfaatkan metode etnografi, maka informasi yang dikumpulkan akan lebih akurat. Etnografi berasal dari kata etno dan grafi, yang berarti etnik dan daerah. Infomasi-informasi dapat diperoleh dengan terlibat secara langsung dan wawancara dengan seluruh elemen masyarakat untuk mendengarkan mimpi untuk dirinya sendiri maupun masyarakat setempat. ${ }^{11}$

Pada Gambar 5 menunjukkan mahasiswa sebagai fasilisator pelatihan Tech for Kids memberikan pandangan-pandangan yang diperlukan untuk melatih siswa dan siswi mengenal etnografi dan melakukan observasi terhadap lingkungan sekitarnya. Siswa dan siswi melakukan brainstorming terhadap permasalahan yang ada di sekitarnya. Masingmasing siswa menyampaikan secara cepat. Setiap pendapat dapat diterima. Proses brainstorming dikenal juga dengan sebutan proses divergent. Curahan gasan merupakan bagian penting seorang rekayasawan untuk mempu menghasilkan inovasi yang bermanfaat secara luas di sekolah nantinya.

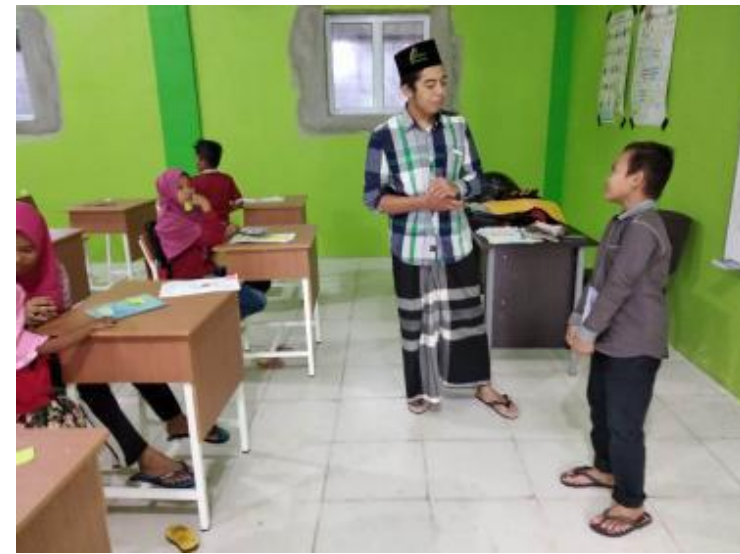

Gambar 5. Mahasiswa Sebagai Fasilisator Pelatihan Tech For Kids Melatih Siswa Dan Siswi Mengenal Etnografi Dan Melakukan Observasi Terhadap Lingkungan Sekitarnya

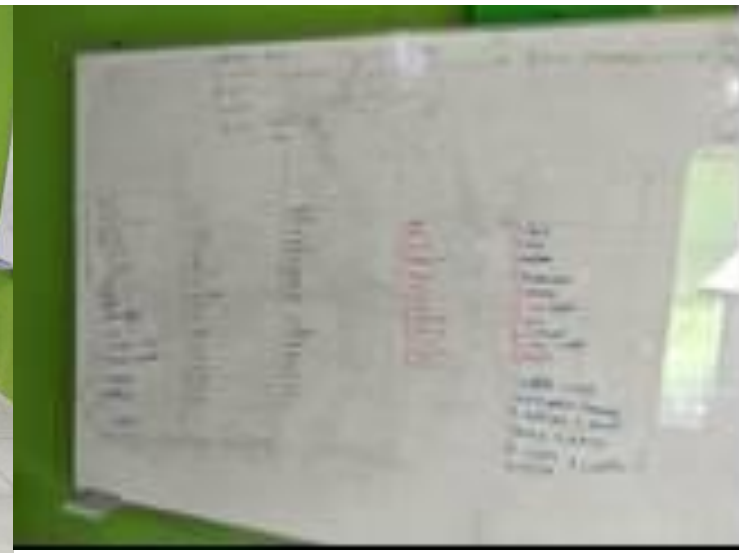

Gambar 6. Siswa Dan Siswi Melakukan Brainstorming

\footnotetext{
${ }^{11}$ Sapti Prihatmini, Dina Tsalist Wildana, Fanny Tanuwijaya, Al Khanif, Jauhari Zakkiy Annas. 2020. Anak di Embung Cinta: Pembentukan Wisata Ramah Anak di Kelurahan Nangkaan Bondowoso, Warta Pengabdian, Vol. 14, No. 3, hal 173-180
} 


\section{B. Menentukan Permasalahan dan Solusi Utama}

Setelah mengumpulkan permasalahan-permasalahan yang ada di sekolah, selanjutnya akan dilakukan pengelompokan untuk menentukan permasalahan utama nantinya. Pada Gambar 7 menampilkan siswa menjelaskan permasalahan utama ditemukan setelah melalui proses pengerucutan permasalahan-permasalahan yang sudah didokumentasikan.

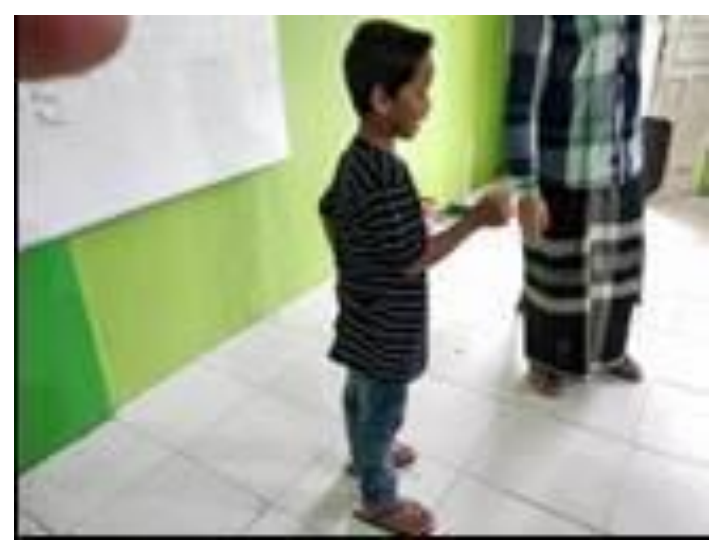

Gambar 7. Siswa Menyamapaikan Permasalahan Utama Yang Ditemukan

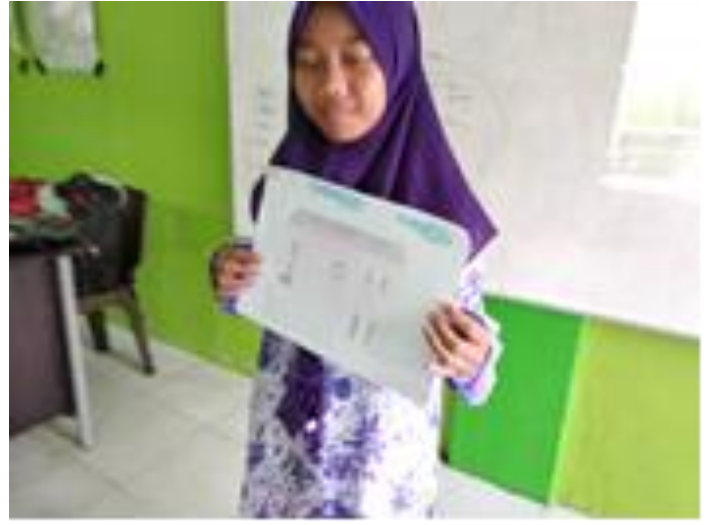

Gambar 8. Proses Curahan Gagasan Untuk Mendorong Siswa Dalam Meberikan Solusi Utama Secara Bebas

Adapun solusi utama yang diambil adalah merupakan solusi yang akan berdampak luas untuk calon pengguna nantinya. Dalam tahapan ini disampaikan beberapa konsep solusi bersama anggota siswa lainnya. Dengan mempergunakan alat tulis yang dituangkan kedalam sketsa pada gambar.

\section{Sketching dan Purwarupa Virtual}

Sketching mendorong siswa untuk mampu menyampaikan ide-ide yang telah disampaikan lewat brainstorming. Proses ini sudah diterapkan oleh para insinyur pada tahap awal perancangan. Pada Gambar 9 menampilkan siswa mensketsa diatas kertas. Sedangkan pada Gambar 10 menunjukkan siswa melakukan proses transformasi dari sketsa yang digambar di atas kertas ke komputer. 


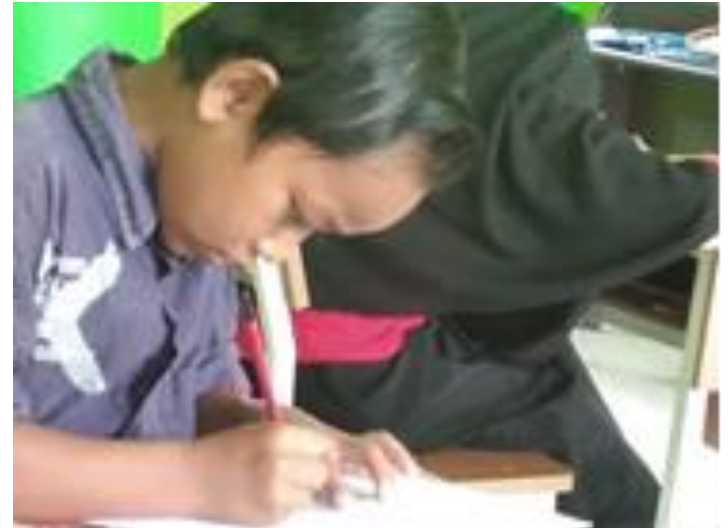

Gambar 9. Mensketsa di atas kertas

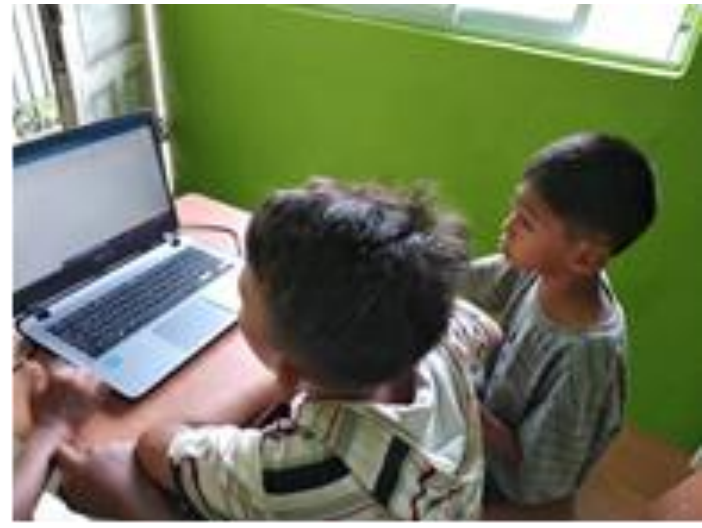

Gambar 10. Pembuatan Purwarupa Virtual Dari Sketsa

Dengan menggunakan purwarupa memungkinkan desainer mengeksplorasi dan memvalidasi ide sebelum menginvestasikan terlalu banyak sumber daya dalam membangun produk yang sebenarnya. Adapun Purwarupa fisik dan visual memiliki tujuan yang sama namun dengan cara pencapaian yang berbeda

\section{Purwarupa Fisik Sederhana}

Tahapan pembuatan purwarupa adalah merupakan tahapan dari EDP yang sudah mulai memerlukan pembiayaan. Oleh sebab itu pada tahapan ini, perancang akan memulai pembuatan purwarupa yang ekonomis dan fleksibel, dengan maksud bahwa perubahan rancangan dapat dilakukan dengan mudah dan tidak akan memerlukan pembiayaan yang besar, seperti pada Gambar 1l. Penggunaan bahan yang ekonomis dan mudah ditemukan dimaksudkan untuk memudahkan siswa untuk melakukan perubahan apabila diperlukan.

Purwarupa fisik dipergunakan sebagai media untuk mendapatkan gambaran jelas mengenai inovasi yang dimaksud dan alat bantu untuk mempelajari produk yang sudah ada sehingga pada ahirnya purwarupa memiliki kontribusi jelas untuk pengambilan keputusan didalam peluncuran produk di pasaran. Untuk menyelidiki masalah terkait kinerja purwarupa yang dihaSilahkann, maka dilakukan integrasi sistem, dimana maka siswa dan mahasiswa bersama-sama merakit sistem elektronika pada purwarupa fisik sederhana yang sudah dihasilkan oleh siswa pada gambar 12. 


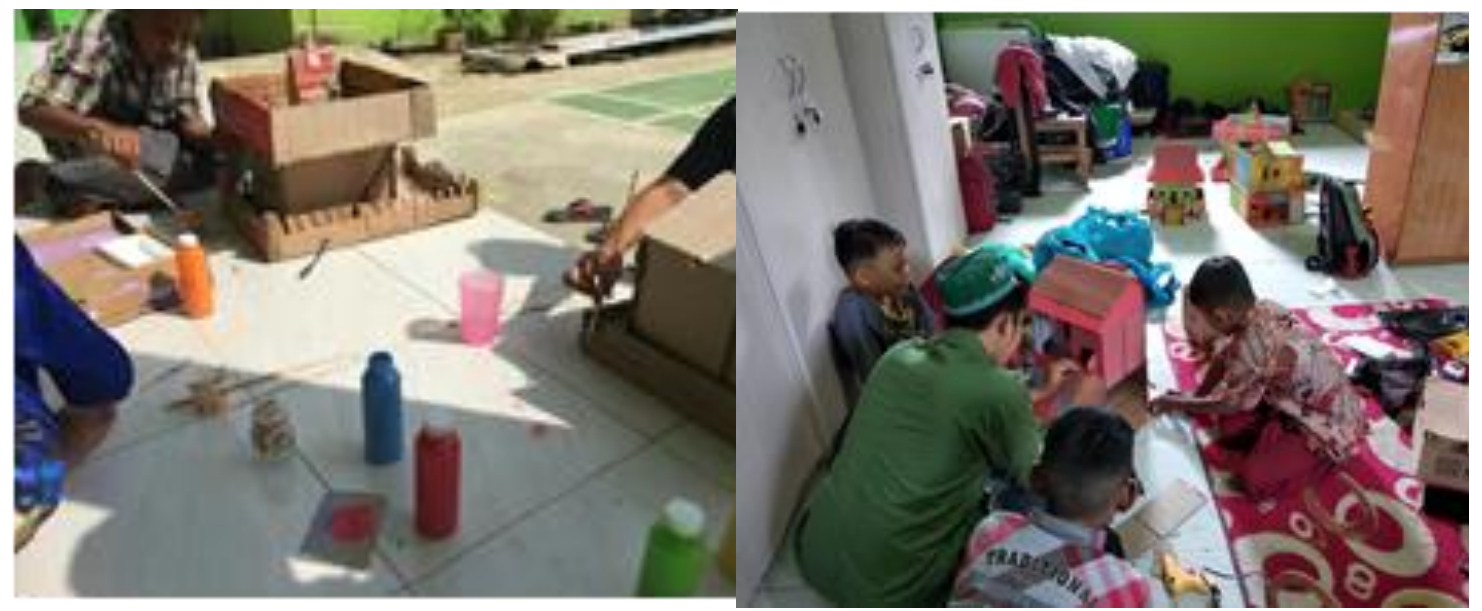

Gambar 1l. Perakitan Purwarupa Fisik Gambar 12. Perakitan Sistem Elektronika Sederhana Dan Ekonomis Pada Purwarupa Fisik

\section{KESIMPULAN}

Kegiatan Tech for Kids, adalah pelatihan rutin mingguan untuk siswa \sekolah dasar guna mendorong siswa dan sekolah untuk meningkatkan pengetahuan dengan penguasaan teknologi dan meningkatakan prestasi siswa di sekolah atau daearah. Kemampuan berfikir secara luas yang diperkenalkan didalam proses pembelajaran TFK, mampu menyadarkan siswa akan pentingnya teknologi. Demikian juga sekolah yang termotivasi untuk mendorong siswa tidak hanya menjadi pengguna teknologi. Meningkatnya keinginan siswa selama kegiatan berlangsung telah menunjukkan keberhaSilahkann dari pelatihan TFK.

Tech for Kids merupakan sebuah pelatihan yang dapat dilaksanakan akibat adanya kerjasama yang baik dengan pihak sekolah, diharapkan untuk kedepannya dapat juga melibatkan pemerintah daerah untuk mengadakan kegiatan serupa untuk memasyarakatkan teknologi pada anak usia sekolah, dengan demikian akan mempersiapkan generasi yang mampu bersaing secara global. Dengan adanya mahasiswa sebagai fasilisator, dapat mendorong siswa untuk lebih antusias didalam memahami materi proses perancangan rekayasa, oleh sebab itu pola seperti ini juga dapat diterapkan di sekolah untuk mata pelajaran tertentu yang mengajarkan ilmu teknik.

\section{UCAPAN TERIMA KASIH}

Ucapan terima kasih kami sampaikan terutama kepada Lembaga Penelitian, Pengabdian Masyarakat dan Penjaminan Mutu (LP3M), Universitas Maritim Raja Ali Haji sesuai dengan perjanjian pendanaan pelaksanaan program Pengabdian Kepada Masyarakat Nomor: 053/UN53.02/Kontrak-PKM/I/2020, 01 April 2020. Selain itu, juga disampaikan terima kasih kepada mahasiswa dan dosen yang terlibat di jurusan teknik perkapalan 
dan elektro UMRAH serta Sekolah Madrasah Ibtidaiyah Raudhatul Qur'an di Tanjungpinang Timur

\section{DAFTAR PUSTAKA}

Luh Putu Indah Budyawati, Arie Rahayu Hariani, Wiwin Hartanto. 2020. Mengadopsi Model Akuntansi Startup untuk UMKM: Studi Kasus pada Pengerajin Kayu Desa Grenden, Kabupaten Jember, Warta Pengabdian, Vol. 14, No.3, hal 181-190

Lyn D. English Donna KingDonna King, 2015, STEM learning through engineering design: fourth-grade students' investigations in aerospace, International Journal of STEM Education, Vol. 2, No. 1

Madrasah Ibtidaiyah Raudhatul Qur'an [Daring], Tersedia pada : https://maps.app.goo.gl/1FyEQSRZQ6pjScjT9 [ Diakses : 16 September 2020 ].

Novi Anoegrajekti, Sudartomo Macaryus, Asrumi, Hanni Miladia Maharani. 2020 Diversifikasi Usaha Sanggar Seni untuk Meningkatkan Kesejahteraan, Warta Pengabdian, Vol. 14, No. 1, hal 9-22

Nur Rosliana Mohd Hafiz and Shahrul Kadri Ayop, 2019. Engineering Design Process in Stem Education: A Systematic Review, International Journal Of Academic Research In Bussines and Social Sciences, Vol. 9, No. 5, hal. 676-697

Ridho Alfarisi, Robiatul Adawiyah, Lusiana Ulfa Hardinawati, Mutiara Bilqis. 2020.

Pendampingan Pengolahan "Bolen Durian Lumer" Sebagai Produk Unggulan Desa

Pakis Dalam Peningkatan Perekonomian Masyarakat, Warta Pengabdian, Vol. 14, No. 2, hal 78-86

Rizqi Ilmal Yaqin, Boby Wisely Ziliwu, Bobby Demeianto, Juniawan Preston Siahaan, Iskandar Musa, Yuniar Endri Priharanto, Rudi Efendi, Muhammad Ali Rozaki, Nirmala Efri Hasibuan, Muhammad Nur Arkham. 2020. Edukasi Perawatan Motor Diesel Kapal Nelayan Desa Pelintung Kota Dumai, Warta Pengabdian, Vol. 14, No. 3, hal 200-209

Rosnida Sari, Sutri Sanova. 2020. Faktor Anak Bekerja di Tambang Emas:Studi Kasus di Tambang Emas Blang Leumak, Aceh Jaya, Warta Pengabdian, Vol. 14, No. 2,hal 94 107

Sapti Prihatmini, Dina Tsalist Wildana, Fanny Tanuwijaya, Al Khanif, Jauhari Zakkiy Annas. 2020. Anak di Embung Cinta: Pembentukan Wisata Ramah Anak di Kelurahan Nangkaan Bondowoso, Warta Pengabdian, Vol. 14, No. 3, hal 173-180

Siew, NM, Goh, H, Sulaiman, F, 2016. Integrating Stem In An Engineering Design Process: The Learning Experience Of Rural Secondary School Students In An Outreach Challenge Program, Journal of Baltic Science Education, Vol 15, No. 4, hal 477-493.

Teaching The Engineering Design Process - STEM Activities for Kids [Daring], Tersedia pada : https://id.pinterest.com/pin/398779741988713981/ [ Diakses : 16 September 2020 ]. 